\title{
Impact of Foreign Direct Investment of Indian Economy in Epoch of Global Value Chain with Reference to Industrialists in Tirunelveli District
}

\author{
Giftson Solomon J, D Janis Bibiyana
}

\begin{abstract}
A foreign direct investment (FDI) is an investment in the form of controlling ownership in a business in one country by an entity based in another country. It is thus distinguished from a foreign portfolio investment by a notion of direct control. Foreign direct investment (FDI) is an investment made by a firm or individual in one country into business interests located in other country. Generally, Foreign direct investment (FDI) takes place when an investor establishes foreign business operations or acquires foreign business assets, including establishing ownership or controlling interest in a foreign company. Foreign direct investment (FDI) in India is a major monetary source for economic development in India. Foreign companies invest directly in fast growing private Indian businesses to take benefits of cheaper wages and changing business environment of India. Foreign Direct Investment (FDI) gives both positive and negative impacts on Indian economy in epoch of global value chain. The global value chain $(G V C)$ describes the people and activities involved in the production of a good or service and its supply, distribution, and post-sale activities (also known as the supply chain) when activities must be coordinated across geographies. A supply chain is the network of all the individuals, organizations, resources, activities and technology involved in the creation and sale of a product from the delivery of source materials from the supplier to the manufacturer, through to its eventual delivery to the end user. International production, trade and investments are increasingly organized within so-called global value chains (GVCs) where the different stages of the production process are located across different countries. Industrialists are having different thoughts on impacts of Foreign Direct Investment (FDI) on Indian economy.
\end{abstract}

Keywords : Foreign direct investment (FDI), Global value chain (GVC), Supply chain, Industrialists, Indian economy.

\section{INTRODUCTION}

A supply chain is a network between a company and its suppliers to produce and distribute a specific product to the final buyer. This network includes different activities, people, entities, information and resources. The supply chain also represents the steps it takes to get the product or service from its original state to the customer. Supply chains are developed by companies so they can reduce their cost and

Revised Manuscript Received on September 25, 2019

* Correspondence Author

GIFTSON SOLOMON J, Ph.D. Research Scholar, P.G. and Research Department of Commerce, St. John's College (Affiliated to Manonmaniam Sundaranar University), Palayamkottai - 627002

DR D JANIS BIBIYANA, Research Supervisor, Assistant Professor, P.G. and Research Department of Commerce, St. John's College, (Affiliated to Manonmaniam Sundaranar University) Palayamkottai - 627002 remain competitive in the business landscape. A supply chain involves a series of steps involved to get a product or service to the customer. The steps include moving and transforming raw materials into finished products, transporting those products and distributing them to the end user. The entities involved in the supply chain include producers, vendors, warehouses, transportation companies, distribution centers, and retailers. The elements of a supply chain include all the functions that start with receiving an order to meeting the customer's request. These functions include product development, marketing, operations, distribution networks, finance, and customer service. The value chain describes the full range of activities that firms and workers do to bring a product/good or service from its conception to its end use and beyond. This includes activities such as design, production, marketing, distribution and support to the final consumer. A supply chain differs from a value chain. A supply chain emphasizes the manufacturing and distribution-related steps, whereas a value chain also includes the importance of other activities such as design and branding that add value to a product, but do not necessarily reflect a physical transformation. A value chain contained within a geographic location or even a single firm (think about a fruit that is grown, packaged, sold and consumed within one country). A global value chain is divided among multiple firms and geographic spaces. For example a computer uses labor and material from multiple suppliers in different countries, is assembled in another country, and was designed and will ultimately be sold in other places. The GVC initiative is particularly interested in understanding value chains that are divided among multiple firms and spread across several locations, hence the term "global value chain".

\section{Objectives:}

- To know about Foreign direct investment (FDI).

- To know the impact of foreign direct investment of Indian economy in epoch of global value chain.

- To measure the satisfaction level of industrialists in tirunelveli district.

- To offer major findings and suggest suitable measures to overcome the problems identified in the present study. 


\section{Methodology}

The study being based on primary data on the impact of foreign direct investment is collected through a suitable framed questionnaire. Besides the responses received on the questionnaire, informal discussions were held with the industrialists to get insight into various matters connected with their work life balance. Secondary data include books, journals, websites etc. 50 industrialists in tirunelveli district were selected as sample for the present study by using Simple random sampling method. Data collected have been presented in tabular form and the analysis was made using simple percentage, weighted average and chi-square.

\section{Impact of foreign direct investment (FDI):}

Foreign direct investment (FDI) is an investment from a party in one country into a business or corporation in another country with the intention of establishing a lasting interest. Lasting interest differentiates FDI from foreign portfolio investments, where investors passively hold securities from a foreign country. A foreign direct investment can be made by obtaining a lasting interest or by expanding one's business into a foreign country. Foreign direct investment is an investment in a business by an investor from another country for which the foreign investor has control over the company purchased. Businesses that make foreign direct investments are often called multinational corporations (MNCs) or multinational enterprises (MNEs). An MNE may make a direct investment by creating a new foreign enterprise, which is called Greenfield investment, or by the acquisition of a foreign firm either called an acquisition or brownfield investment. The investment climate in India has improved considerably since the opening of the economy in 1991. This is largely attributed to ease in FDI norms across sectors of the economy. With an aim to attract and promote FDI, Government of India has put in place a policy framework on FDI, which is transparent, predictable and easily comprehensible. FDI inflows in telecommunication, construction, development, pharmaceuticals and power sectors declined significantly in 2018-2019. Foreign direct investment (FDI) in India declined for the first time in the last six years in 2018-2019, falling by 1 per cent to $\$ 44.37$ billion as overseas fund inflows subsided in telecom, pharma and other sectors, official data showed. According to the latest data of the department for promotion of industry and internal trade (DPIIT) FDI in 2017-2018 was a record $\$ 44.85$ billion. Foreign direct investment in telecommunication dropped to $\$ 2.67$ billion in 2018-2019 from $\$ 6.21$ billion in 2017-2018 in construction development to $\$ 213$ million (\$540 million), in pharmaceuticals to $\$ 266$ million (\$1 billion) and in the power sector to $\$ 1.1$ billion ( $\$ 1.62$ billion). Sectors that recorded a growth in FDI includes services
(\$9.15 billion), trading $(\$ 4.46$ billion $)$ and automobile (\$2.62 billion).

\section{Analysis of data:}

Table 1:Socio economic profile of the respondents

\begin{tabular}{|c|c|c|c|}
\hline Variables & & $\begin{array}{l}\text { No. of } \\
\text { respondents }\end{array}$ & Percentage \\
\hline \multirow[t]{2}{*}{ Gender } & Male & 28 & 56 \\
\hline & Female & 22 & 44 \\
\hline \multirow[t]{5}{*}{ Age } & Below 25 & 3 & 6 \\
\hline & $25-35$ & 18 & 36 \\
\hline & $35-45$ & 13 & 26 \\
\hline & $45-55$ & 10 & 20 \\
\hline & Above 55 & 6 & 12 \\
\hline \multirow{2}{*}{$\begin{array}{l}\text { Marital } \\
\text { status }\end{array}$} & Married & 47 & 94 \\
\hline & Unmarried & 3 & 6 \\
\hline \multirow{2}{*}{$\begin{array}{l}\text { Educational } \\
\text { Qualificatio } \\
\mathrm{n}\end{array}$} & $\begin{array}{l}\text { Below } \\
\text { degree }\end{array}$ & 12 & 24 \\
\hline & $\begin{array}{l}\text { Degree and } \\
\text { above }\end{array}$ & 38 & 76 \\
\hline \multirow{2}{*}{$\begin{array}{l}\text { Industry } \\
\text { Area }\end{array}$} & Rural & 30 & 60 \\
\hline & Urban & 20 & 40 \\
\hline \multirow{4}{*}{$\begin{array}{l}\text { Period of } \\
\text { doing } \\
\text { business }\end{array}$} & $\begin{array}{ll}\text { Below } & 5 \\
\text { years }\end{array}$ & 6 & 12 \\
\hline & 5-15 years & 32 & 64 \\
\hline & 15-25years & 20 & 40 \\
\hline & $\begin{array}{l}\text { Above } 25 \\
\text { years }\end{array}$ & 2 & 4 \\
\hline
\end{tabular}

Source: Primary data.

According to the above table, it is clearly analyzed that $56 \%$ of the respondents are male, $36 \%$ of the respondents belong to 25-35 years, $94 \%$ of the respondents are married, $76 \%$ of the respondents are graduates, $60 \%$ of the respondents are having industry in rural area and $64 \%$ of the respondents are doing business for 5-15 years.

Table 2: Respondents opinion about FDI procedures in India

\begin{tabular}{|l|l|l|l|l|l|}
\hline Sl.No. & Particulars & $\begin{array}{l}\text { No. of } \\
\text { respondents } \\
(\mathrm{W})\end{array}$ & $\begin{array}{l}\text { Value } \\
(\mathrm{X})\end{array}$ & WX & Rank \\
\hline 1 & Excellent & 13 & 5 & 65 & II \\
\hline 2 & Very Good & 18 & 4 & 72 & I \\
\hline 3 & Good & 10 & 3 & 30 & III \\
\hline 4 & Average & 8 & 2 & 16 & IV \\
\hline 5 & Poor & 1 & 1 & 1 & V \\
\hline & Total & 50 & & 184 & \\
\hline
\end{tabular}

Source: Primary data.

Mean score $=184 / 50$

$$
=3.68 \text {. }
$$


According to the above table, 18 respondents felt that procedures are very good with weight mean score of 72,13 respondents felt that procedures are excellent with weight mean score of 65,10 respondents felt that procedures are good with weight mean score of 30,8 respondents felt that procedures are average with weight mean score of 16 and 1 respondent felt that procedures are poor with weight mean score 1.

\section{Chi-Square analysis:}

Table 3:Gender and satisfaction level of the respondents Null hypothesis - There is no significant association between gender of the respondents and satisfaction level of the respondents.

\begin{tabular}{|l|l|l|l|l|l|l|}
\hline & $\begin{array}{l}\text { Highl } \\
\text { y } \\
\text { satisfi } \\
\text { ed }\end{array}$ & $\begin{array}{l}\text { Satisfi } \\
\text { ed }\end{array}$ & $\begin{array}{l}\text { No } \\
\text { opini } \\
\text { on }\end{array}$ & $\begin{array}{l}\text { Dis } \\
\text { satisfie } \\
\text { d }\end{array}$ & $\begin{array}{l}\text { Highly } \\
\text { dissatis } \\
\text { fied }\end{array}$ & Total \\
\hline Male & 6 & 10 & 5 & 3 & 4 & 28 \\
\hline $\begin{array}{l}\text { Fema } \\
\text { le }\end{array}$ & 6 & 8 & 2 & 4 & 2 & 22 \\
\hline Total & 12 & 18 & 7 & 7 & 6 & 50 \\
\hline
\end{tabular}

Source: Primary data

Degree of freedom $=4$

Table value of $X$ for degree of freedom $=4$ and at $5 \%$ level of significance $=9.488$

Computed value $=1.6208$

Comparing the table value of $\mathrm{X}$ [9.488], with the computed value of $X$ [1.6208], the calculated value of $X$ is less than the table value and so the Null hypothesis is accepted. That is, there is no association between gender and satisfaction level of industrialists.

\section{FINDINGS AND SUGGESTIONS}

- $56 \%$ of the respondents are male.

- $36 \%$ of the respondents are belong to 25-35 years.

- $94 \%$ of the respondents are married.

- $76 \%$ of the respondents are graduates.

- $60 \%$ of the respondents are having industry in the rural area.

- $64 \%$ of the respondents are doing business for 5-15 years.

- 18 respondents are felt that FDI procedures are very good.

- There is no association between gender and satisfaction level of the respondents in tirunelveli district.

- Government should give guidance to all industrialists about how to use FDI in their business.

- Government should provide loans to local industrialists for doing business smoothly.

\section{CONCLUSION}

FDI is important as India would require huge investments in the coming years to overhaul its infrastructure sector to boost growth. Decline in foreign inflows could put pressure on the country's balance of payments and may also impact the value of the rupee.

\section{REFERENCES}

1. www.thehindubusinessline.com

2. www.businessstandard.com

3. www.ibef.org

4. www.makeinindia.com

5. www.corporatefinanceinstitute.com

6. www.investopedia.com 